\title{
Central business district planning and the sustainable urban development process in Istanbul
}

\author{
A. E. Erbas \\ City and Regional Planning Department, Faculty of Architecture, \\ Mimar Sinan Fine Arts University, Turkey
}

\begin{abstract}
Istanbul has always been the core of different civilizations in history. As the capital city of the Ottoman Empire, Istanbul's modern place within the world economy began in the late eighteenth century with the disintegration of the Ottoman Empire and the growth of modern European capitalism. Istanbul Metropolitan Areas has been experiencing a massive pressure to transform itself into a "World City" with the help of emerging neo-liberal urban policies after the 1990s. Radical changes in the world politics after 9/11 and increasing energy demand have made Istanbul a candidate for a regional hub to financial flows and energy corridors. International capital sees Istanbul as likely to be the command and control centre for the Balkans, the Middle East, the Black Sea Region, and some of the Central Asian Republics of the former Soviet Union. From this point of view, it has a strategic geographical location which promotes competitive economy at EU level. This paper initially contains an analytical perspective. This perspective informs the analyses of the evolution of urban regeneration legislations in Turkey. Also, a literature review was made about the transition in Istanbul under the process of globalization. The results of dynamics of urbanization have come up for discussion. In this paper the relationships between the Central Business District in decentralization process and the vision of the Istanbul Metropolitan Plan for 2023 are discussed. The focus of the research case is the Zincirlikuyu-Maslak Axis; a new enterprise site in the Istanbul Metropolitan area. These kinds of urban projects in the Zincirlikuyu-Maslak area should be seen as a means not only to convert the areas into more attractive spaces but also to regenerate the economy of both the city and the local region.

Keywords: Metropolitan Plan, CBD, sustainable urban development.
\end{abstract}




\section{Introduction}

Urbanisation is among the most significant social and economic phenomena in our age. Since the first human settlements, cities have been the most complicated artificial structures. Even from the 1950s urban population has quadrupled. Therefore, it is possible to call our age an age of "urban revolution" [1]. The predominant activities in cities were agriculture and commerce until the industrial revolution in the 19th century. Particularly after the industrial revolution, human beings have begun to misbalance their relations with the nature to their benefit.

Industrialisation is "an activity that causes cities to emerge" [2]. This process has two impacts on urban settlements. Firstly, older cities with traditional structures sprawled due to industrialisation. Secondly, industrialisation itself paved the way for founding new cities. With regard to these two different paths, the city of Istanbul belongs to the first category. Due to the rapid industrialisation, particularly since the 1950s, Istanbul has turned into "an enormous industrial city" [3]. Because the industrial sector necessitated vast amount of labour force, initially urbanisation occurred as a process of population accumulation. In addition to the population growth, industrialisation led to specialisation and division of labour. Furthermore, rapid industrialisation and population growth caused an increase in number of motor vehicles and energy consumption, agricultural mechanisation, concentration of production and consumption in cities whose population are over one million and several problems in social and physical environment. The urban geography plays an important role in locations of industrial functions and provision of the basic needs of urban dwellers. In this context, in addition the physical conditions of urban geography, humane and economic conditions and transportation issues have become equally important. With regard to these networks, issues concerning planned urbanisation were put on the agenda in these times. Due to industrialisation, the city of Istanbul, has economically developed and spatially sprawled. The traditional centre of Istanbul long remained in the Historical Peninsula and Galata; however several developments occurred since the 19th century. In the last 30 years, the view, which suggests sustainability of the city does not only depend on economic development but also on ecological and social issues, has been widely acknowledged. In the Istanbul case, ecological dimension of city's spatial development has been discussed after the 1980s. In line with the urban sprawl, the relations between residential areas, business districts, investments on infrastructure and transportation, labour opportunities and local development strategies were studied. These relations were examined mostly through economic and social developments. However, in the last 30 years, The Metropolitan Plans of Istanbul were highly concerned with ecological issues. These plans included decisions towards the preservation of forests, rural settlements and water basins which are located in the north part of the city. The Istanbul Metropolitan Plan, 1/100.000 scale and approved in 2009, stated this vision: "with regard to environmental, social and economic principles of sustainability and conservation of the city's original cultural and natural identity, 
to transform Istanbul into a city of high life quality; into a competitive power in the global scale with its information society" [4]. Concerning this vision, main objectives of this vision are to prevent central business district of the city from developing towards to the north parts of the city and conservation of the city's natural resources. However, due to Istanbul's rapid transformation from an industrial city to a commercial city, Central Business District (CBD) both developed in the traditional centre and gained a polycentric structure [5]. This is due to a defacto situation rather than a master plan. The powerful local dynamics of Istanbul, which is constantly supported by the central government, the existence of urban projects that alter urban spatial forms despite contrary decisions by the local governments influenced this defacto situation.

In addition to migration, international capitals' needs to create new markets led to the restructuring of Istanbul and consequently there has been a shift from the industrial sector to the service sector. As a result of competition and increasing access to the world markets, economies are no longer dependent upon industries but upon services. In this new structure, international finance centres hierarchically direct world markets [6]. The city of Istanbul also desires a place in the network of these financial centres. Consequently, new spatial policies caused an institutional restructuring in the context of relations between global forces and local dynamics [7]. Therefore in the last decade, several laws and regulations concerning spatial planning were issued as shown in table 1 , and

Table 1: $\quad$ Significant legal arrangements concerning urban regeneration in Turkey.

\begin{tabular}{|l|l|l|}
\hline Date & $\begin{array}{c}\text { Law } \\
\text { Number }\end{array}$ & \multicolumn{1}{c|}{$\begin{array}{c}\text { Law* } \\
\text { *abbreviated) }\end{array}$} \\
\hline 1966 & 775 & Squatter Housing (Gecekondu) Law \\
\hline 1984 & 2981 & $\begin{array}{l}\text { Law on Buildings Violating Development and Squatter } \\
\text { Housing (Gecekondu) Regulation }\end{array}$ \\
\hline 1984 & 2985 & Mass Housing Law \\
\hline 1985 & 3194 & Development Law \\
\hline 1994 & 4046 & Privatisation Law (Article 41) \\
\hline 1997 & 4232 & Privatisation Law (Article 4) \\
\hline 2004 & 5104 & North Ankara Exit Urban Regeneration Project Law \\
\hline 2004 & 5162 & Amendment in Mass Housing Law \\
\hline 2004 & 5226 & $\begin{array}{l}\text { Amendment in Law for Protection of Cultural and Natural } \\
\text { Heritage }\end{array}$ \\
\hline 2005 & 5393 & Municipality Law \\
\hline 2005 & 5366 & $\begin{array}{l}\text { Law for Renovation, Protection, Cherishing and Use of } \\
\text { Worn Historical and Cultural Immovable Properties }\end{array}$ \\
\hline 2010 & 5998 & Amendment in the Municipality Law \\
\hline 2011 & 644 & $\begin{array}{l}\text { Foundation of the Ministry of Environment and City } \\
\text { Planning and Its Objectives }\end{array}$ \\
\hline 2012 & 6306 & $\begin{array}{l}\text { The Law and Regulations on Transformation of Areas } \\
\text { That are Considered Vulnerable to Natural Disasters }\end{array}$ \\
\hline
\end{tabular}


urban regeneration projects were implemented in Istanbul. Due to these new legal arrangements, it is observed that central government's role in spatial decisions about Istanbul has increased.

The most effective decisions of the central government on Istanbul are speculative projects of the government such as new residential areas that were not envisaged by the metropolitan plan and construction of a third bridge and airport for the city. Apart from these, The Marmaray Metro and Tunnel Projects, which were approved by the metropolitan plan, are remarkable transportation investments to organize urban space. In this form, planning agenda of the city is predominantly determined by the central government and its plans and projects. Urban regeneration is now not only related with reorganization of informal residential areas but it is also connected to reproducing the urban space as a whole [8]. In this context, several infrastructure and transportation investments were made. These investments directly influence central business districts. It is impossible to think the Istanbul Metropolitan Area separately from issues such as regional competition, globalisation, environmental problems, information society and urban quality. It is essential to consider the metropolitan plan's objectives concerning commerce and service areas and particularly central business districts in the context of urban/regional competition. Main discussion topics are spatial size, site selection, territory, technological innovations, environmental conditions, technical and social infrastructure, institutional quality, political context, legislation, economic development and ecological sustainability.

\section{Istanbul in transition}

With its 8000 year-old history, Istanbul was the capital of empires in several times. Its history made this city always attractive and drew everyone's attention. Perhaps the city's strategic location played a role in this historical significance. Today Istanbul, with its nearly 14 million inhabitants is even more crowded than several countries in the European Union. The market size stemming from the city's population is intriguing. The 'conurbation' which Istanbul belongs to, is gradually increasing its market share with its spaces of production and consumption [9]. In addition to its geographical location, the city's superiority in terms of social and technical infrastructure, make Istanbul more dynamic and vibrant. Aftermath of the 9/11 incident, both the government and local authorities have begun to make decisions to convert this dynamic and vibrant city to a significant regional cultural and financial centre. However, it is not easy to provide municipal services in a city of huge industrial production and increasing amount of services. The increase and variation of these services is closely connected to socio-economic transformation of Istanbul, particularly after the 1980s [5, 10]. Concepts like globalisation, neoliberal policies, new world order, single market, new regionalism and multinational corporations have introduced new opportunities to Istanbul to become a world city. Istanbul is influential in the Middle East, Balkans and Caspian Basin as well as it is important in Turkey. The period, which begins with 1980, can be analysed in three stages. The first one is between 1980 and 1989. In this stage, "Reagan" 
in the United States, "Thatcher" in the United Kingdom and "Ozal” in Turkey belong to the same political conjecture. Principles of change and restructuring were determined in this decade. In this stage, Turkey enjoyed the pride of "stepping into a new age". While Turkey welcomed all technological innovations, several dubious social issues emerged. In this stage, impacts of modernism could be clearly observed in municipal activities. The second stage covers a five-year old period from 1989 to 1994. Populist inclinations were influential in municipal activities. In this stage, new economic and political decisions shaped Istanbul's spatial development and provided a new identity to the city. The city sprawled more rapidly. On the other hand, new residential areas emerged and current settlements developed. The last stage began in 1994. This stage was dominated by conservative-liberal politics and later single party government. Liberal policies issued by the government have particularly been effective after the 9/11 incident and Istanbul was determined as a financial centre. The developments since the 1990s in line with the globalisation phenomenon are particularly interesting. This approach stresses on the attractiveness of international capital and the "World City" concept. It also includes expectations which will influence Istanbul's future identity.

In this period, Istanbul's spatial structure was affected by three elements of change:

- Process of change in central business districts and sub-centres of the city.

- New axes of spatial development emerge in the urban structure.

- Change in residential areas.

Two major factors affect process of change in central business districts and sub-centres of Istanbul.

- Decentralisation in the city's industry and consequently shift of industrial areas.

- Growth and concentration of service areas.

In this context, industrial area around Halic, Kazlicesme leather industry area and industrial facilities around Bakirkoy and Levent first experienced transformation. Again in this process, the industrial areas of 1950s, similar to the late industrial areas, were replaced in favour of the service economy. This stage was dominated by the transformation of Istanbul's central business districts (CBD) $[10,11]$. This transformation has two dimensions. Firstly, CBD's conventional form experienced a change. Secondly, new sub-centres developed nearby the metropolitan borders. Accordingly, new sub-centres were added to the city including Eminonu Hanlar Area and CBDs emerged on the Galata, Taksim, Sisli, Mecidiyeköy, Zincirlikuyu, Levent and Maslak axis. In the European side of the city, Silivri, Basın Ekspres Motorway and Bakirköy, in the Asian side Atasehir and Kartal area are now considered as Istanbul's new wing-centres. The city of Istanbul's first central business district (CBD) is the Grand Bazaar and Hanlar Area, which are located in the Historical Peninsula. This historical area has long been a centre of economic, social, cultural and political activities [12]. However, due to the new dynamics of urban development in Istanbul, CBD development in the $19^{\text {th }}$ Century spread to the Galata Area, which was the centre of banking activities and later to Meclis-i Mebusan Avenue and Besiktas where 
insurance companies were located. On the other hand, it is known that CBD development also occurred on the Istiklal Street where consulates, cultural and art institutions and commercial buildings were located and then on the SisliMecidiyeköy axis. After 1980s, in a period of new global flows affecting the world geography, CBD led development in Istanbul emerged in BuyukdereMaslak Axis [13]. After the 1990s, the Taksim-Levent Maslak metro line and its connections was constructing concerning CBD lines. Therefore, the CDB characteristics have become more visible. Industrial facilities on this line, which were built between 1940 and 1950, were directed to other areas due to the Istanbul Industrial Area Plan in 1966. These industrial facilities were located in new areas and replaced by the service industry. In the recent years, these areas have become high level service centres. For instance the Levent neighbourhood, built in the 1950s as a residential area, was replaced small and middle scale companies and holdings [14]. Today, in this CBD dominated line, several highrise buildings of national and international capital increase. It is understood that settlement patterns have impacts on the functions of CDB dominated urban development and high level services in the service sector. Old and traditional urban centres (Eminonu-Karakoy) have lost their "power" relatively due to the new CDB. Huge shopping centres, entertainment areas, spaces of fairs, exhibitions and spectacles, residences and multi-stage office buildings reflect this new CDB's characteristics (fig. 1).

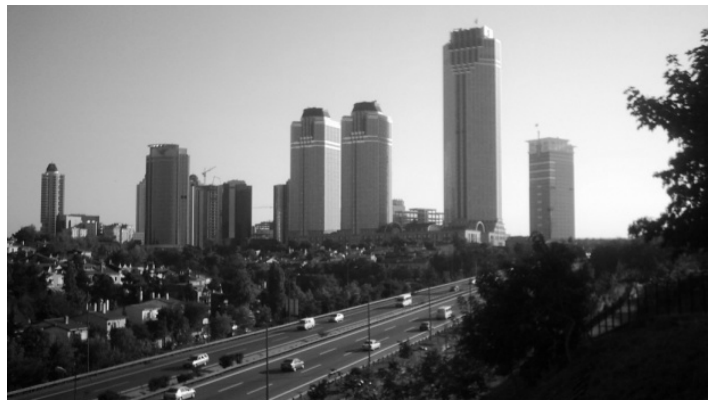

Figure 1: $\quad$ New CBD in Istanbul, a view from Levent area.

Another feature of change in Istanbul from the 2000s, in connection with the CBD development, is "spatial development axes". Configurations on these axes are commercial buildings, which are separated from conventional urban centres. These buildings located on the development axes emerged due to the change and transformation of the city's centre and function areas. In other words, these development axes, which reflect the changing side of the city, can be defined as new spaces of shopping, residence, entertainment and work that are concentrated on an axis. Briefly, the development of "huge shopping and office centres", which began with the process of "hypermarketisation" and continued with "skyscraper building”, is the spatial restructuring of this process [10,11]. With regard to this dimension, these new spaces can be defined as the reflective places of globalisation. They can be categorised under six spatial development axes. 
1) Mecidiyeköy-Zincirlikuyu-Levent-Maslak axis.

2) Seyrantepe-Kavacik axis.

3) Kavacik-Atasehir-Kozyatagi-Kartal axis.

4) Baglarbasi-Altunizade-Umraniye-Cekmekoy axis.

5) Bakirköy-Yenibosna-Bagcilar-Ikitelli axis.

6) Avcilar-Beylikduzu-Haramidere axis.

In this last period, urban dynamics that can influence the Istanbul metropolitan area and particularly spatial development axes are summarised below.

\section{A new public management model}

A new public management model was developed for Istanbul, which is a prime city in Turkey. The Municipality Law (5393) and The Metropolitan Municipality Law (5216) were issued in order to consolidate local governments. By this law, the borders of the Istanbul Metropolitan Municipality were extended to the borders of the province of Istanbul. In addition, with The Metropolitan Municipality Law (6360) in 2012, all rural administrative bodies in Istanbul were abolished, they gained neighbourhood status and they began to be administered directly by the Metropolitan Municipality. Beside, as a development axis of CDB, several neighbourhoods in the Seyrantepe area were transferred from Sisli District Municipality to Sariyer District Municipality. As a result of these developments, newly created districts will establish significant connections with central business districts and new sub-centres.

\section{Earthquake risks}

After the Marmara Earthquake (17 August 1999), earthquake risks have become an agenda topic in Istanbul. Earthquake precautions play an important role in preparing urban projects concerning residential areas and high-rise buildings. Urban regeneration has been introduced as an effective tool for this issue [8]

\section{Immigration}

Immigration continues to shape the city of Istanbul since the 1950s. In addition to immigrants coming to Istanbul from different cities, there is a certain amount of mobility within the city. In this context, certain population, who seek better life conditions and urban quality, will prefer to live in new residential areas in the future. Therefore, inevitably there will be more investments on transportation to connect new residential areas and working places. The distance between residential areas and working places will influence the emerging new centres.

\section{Urban growth}

Metropolitan growth lead to decentralisation of production centres. This spatial spread of industrial and service sector can be depended on advantageous transportation options and strong communication infrastructure. D 100 and TEM Highways made Kocaeli-Istanbul-Edirne connection as a spatial development corridor (and connection with Europe) more suitable. In this context the links 
between sustainable urban forms and local energy planning policies are increasingly important. Reducing carbon emissions in different urban sectors becomes a high priority in national and international levels.

Turkey signed the Kyoto Protocol on 17 February 2009. Turkish Climate Change Strategy (2010-2020) was structured in April 2010. National Climate Change Action Plan (2011-2023) was approved in July 2011. Also Integrated Urban Development Strategy and Action Plan 2010-2023 (KENTGES) was prepared by the different commissions in 25.10.2010. The one of commission is named as Climate Change, Natural Resources, Ecological Balance, Energy Efficiency and Urbanization. According to these documents; promote the use of renewable energy in new urban structures, to prevent urban heat island effect, promote sustainable urban form and energy efficiency and climate oriented local architecture are key issues for the sustainable urban development.

Within this framework, international and national policies towards reducing carbon emissions need to be implemented at the local level. But limited statements are outlined for the reducing of carbon emissions in the Istanbul metropolitan plan $[4,15]$. In fact Local Climate Change Actions Plans should be prepared under the strategic aim of reducing carbon emissions in neighbourhood level. Especially district municipalities need to put in to action to reduce carbon emissions [15].

\section{Urban quality}

Due to the traffic jam, noise, environmental pollution in the city's residential and working areas and needs for aesthetics, security and infrastructure forced inhabitants, who desire a certain quality of life, to look for alternatives. Creative decisions of investments, which address this emerging market, look for answers to these quests. When weakening ties with the neighbours and low quality of organisation by contrast to the advanced societies are considered, these new areas are important socio-economic places. Although gated communities, residences and shopping centres help to create limited urban and architectural quality, it is not possible to talk about a total urban quality in urban public spaces.

\section{Discussion focuses on challenges of CBD development}

The Istanbul Metropolitan Plan, with a scale of $1 / 100.000$, was accepted on 15.06.2009. Above mentioned developments should be analysed with these changing legal arrangements. In Istanbul, several legal arrangements such as The Metropolitan Municipality Law (5216), Municipality Law (5393) and Provincial Special Administration Law (5302) made provincial and municipal borders of Istanbul to overlap. This situation provided opportunities to the local administration of Istanbul to control urban development dynamics. However, there are still limits of evaluation within the city. Lack of regional development and planning and managerial approach that handles all the investments on the provincial level, caused this situation. The Istanbul Metropolitan Plan Report aims to maintain the balance between predictions of population growth and 
sectoral allocation. The population of Istanbul in 2023, if the current dynamics and trends continue, has been calculated 22-25 million. However when population-employment balance and ecological capacity are considered, the plan assumed that city's population may not exceed 16 million. In this context, Istanbul was divided into 10 sub-areas in order to determine subscale plans in accordance with population and sectoral allocation predictions (fig. 2). In dividing Istanbul into sub-areas, natural and artificial thresholds were taken into consideration

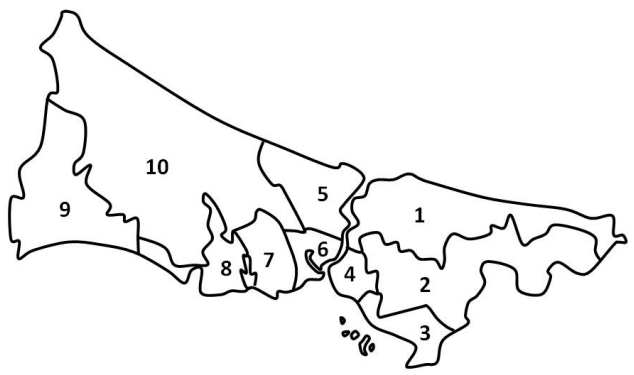

Figure 2: Sub-areas that were suggested in the Istanbul Metropolitan Plan [4].

In the suggested sub-areas, population-employment was focused. Accordingly, sub-area 6 is the centre of Istanbul. Sub-area 6 includes the districts of Besiktas, Sisli, Beyoglu, Eyup, Fatih, Gaziosmanpasa, Sultangazi, Bayrampasa, Zeytinburnu and Kagithane, most of which have CDB functions.

In 2000, the service sector's share in employment was $60 \%$; this is aimed to increase to $80 \%$ whereas the industrial sector's share is aimed to decrease from $31 \%$ to $20 \%$ in 2023. In this context, a transformation from industrial economy to service economy has been planned. However there are several active industrial facilities. Planning decisions force these facilities to decentralisation regardless of their contribution and employment opportunities. The objective of making new places of commerce and business leads to "deindustrialisation" process in the city [16]. There are two approaches in Istanbul's economic transformation concerning spatial dimensions. The first approach deals with the re-use of former industrial landscape for information economy, culture industries and the service sector. The other approach is about creating new centres of attraction and development in the far ends of the city, in Silivri and Tuzla-Kurtkoy. Istanbul has no single centre. When service activities' concentration and distribution patterns are examined, it is possible to define different centres in both European and Asian sides. Currently the CDB, which starts from the Historical Peninsula and extends to Maslak through the Buyukdere axis, developed as a single centred attraction point (fig. 3). The CDB, where high level services concentrated, also paves the way for urban sprawl in the north that is threatening natural areas of the city. In addition, it increases traffic jam between two sides of the city. 
The CDB axis also threatened forests in the north part of the city and the Bosporus as well.

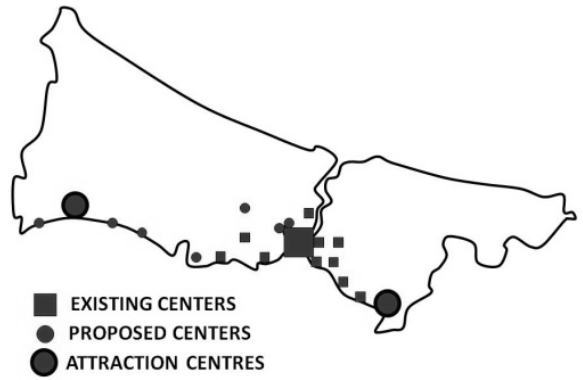

Figure 3: $\quad$ Proposed polycentric urban system in the Metropolitan Area [4].

The city needs a new, modern CBD for new facilities with high-tech infrastructure; however Improvements in Maslak axis make big pressure on growing through north, where lots of natural thresholds exist (fig. 4).

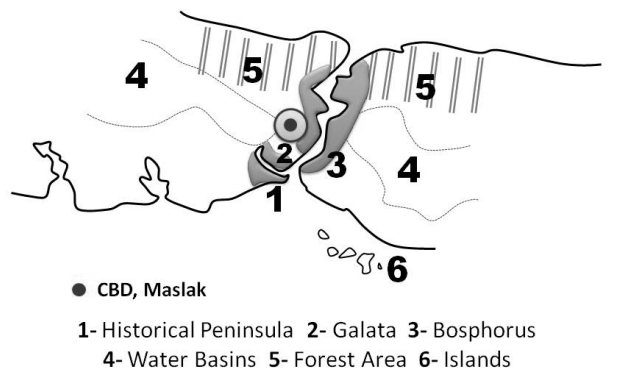

Figure 4: $\quad$ Existing CBD; Buyukdere-Maslak in the city.

The existing CBD in the Istanbul Metropolitan Plan extends to Maslak through the Buyukdere axis as an integration and CDB area. In addition, CDB's potential development area in the west part including Topkapi-MaltepeBayrampasa, is defined as an integration and CDB area. In the Istanbul Metropolitan Plan Report, decision concerning central business districts and integration area are classified under the title of commerce and service centres. This hierarchy of centres in Istanbul was both shaped by private sector investments and government's decisions towards investments. All public banks, particularly the Central Bank in Ankara, consider moving their headquarters to Istanbul. In this context, Atasehir area was determined as a financial centre. With regard to this decision, the Istanbul International Finance Centre unit was established within the scope of the Ministry of Development. The Istanbul International Finance Centre Strategy and Action Plan was prepared by the Supreme Planning Board and published in the Official Gazette on 2 October 2009. According to the Ministry of Environment and Urbanism, this project aims 
to establish a larger financial centre in Istanbul than its counterparts in New York, London and Dubai and to make Istanbul an international finance centre [17]. The project is expected to provide employment for 30,000 people. With the project, an area of 2 million 500 thousand square metre will be opened for construction. However, the project does not only include office buildings; but it also includes shopping centres, hotels and residential areas. In addition to Atasehir Finance Centre, Istanbul's central business districts and first level subcentres are: central business district existing CBD area 1.165 hectare, Silivri international centre (proposed) area 479 hectare, media-express way international centre (proposed) area 662 hectare, Kartal international centre (proposed) area 329 hectare [4]. Nevertheless, none of the projects were announced to the public or no design and planning contests were launched with the exception of the Kartal Sub-Centre Project. In Kartal, the project process created debates. Due to a political preference, Zaha Hadid's urban design project was made public [8].

\section{Conclusion}

- In the Istanbul Metropolitan Plan of 1/100.000 scale, a science and technology based commerce and service economy was anticipated in 2023. However, there is no evaluation about transforming existing industrial facilities.

- Sub-centre creating projects such as the Atasehir and Kartal areas and Urban Development Vision, Strategic Spatial Plan, Strategic Urban Project and Implementation Program were not considered as a whole. The relationships between these projects were not adequately established in the spatial context. It is found that public burdens and public benefits were not shared with the people and participation processes remained limited. It is obvious that public participation and negotiation processes are not sufficient in this planning process; therefore such discussions will no longer provide a solution. It is also clear that there is a need for a metropolitan strategy and innovative planning approach in order to increase the country's competitive capacity.

- A radical transformation in the existing industrial infrastructure is planned. New commerce and service areas are added to the city which experiences "deindustrialisation” process.

- There is an uncertainty about projects of the central government such as the third airport, the third bridge and their possible influence on CDB and subcentre formations.

- It is essential to organise current CDB and integration area as a special project area in order to develop "Cool District” programs [18, 19]. "Cool District" programs should be used to reduce carbon emissions. In order to reduce carbon emissions, reducing energy and water consumption, decreasing private car use and a fine sanitary management are needed. In this context, a "CDB Carbon Master Plan” should be prepared and low carbon vision in CDB should be adopted. 


\section{References}

[1] Bruntland, G., Our common future: The world commission on environment and development, 1987

[2] Tumertekin, E., Turkiye'de sehirlesme ve sehirsel fonksiyonlar: Urbanization and urban functions in Turkey (Vol. 72). Istanbul Universitesi, Edebiyat Fakultesi Matbaası, 1973

[3] Guvenc, M., Metropol degil azman sanayi kenti. Istanbul, 5, pp. 75-81, 1993

[4] BIMTAȘ, 1/100.000 olcekli Istanbul Cevre Duzeni Plani ve Plan Raporu, 2009

[5] Dokmeci, V. \& Berkoz, L. Transformation of Istanbul from a monocentric to a polycentric city. European Planning Studies, 2(2), pp. 193-205, 1994

[6] Sassen, S. Global financial centers. Foreign Affairs, pp. 75-87, 1999

[7] Healey, P. The treatment of space and place in the new strategic spatial planning in Europe. International journal of urban and regional research,28(1), pp. 45-67, 2004

[8] Erbas, A. E. \& Erbil, T. Rethinking the Urban Transformation Projects Again: the Distribution of Public Burden and Benefits. The Case of Kartal District, Istanbul, 2011

[9] Cubuk, M., Istanbul. A Metropolization Process, Urbanistica, Dicembre, (6), 1993

[10] Ozus, E., Turk, S. S. \& Dokmeci, V., Urban restructuring of Istanbul European Planning Studies, 19(2), pp. 331-356, 2011

[11] Ertekin, O., Dokmeci, V., Unlukara, T. \& Ozus, E., Spatial distribution of shopping malls and analysis of their trade areas in Istanbul. European Planning Studies, 16(1), pp. 143-156, 2008

[12] Mortan, K. \& Kucukerman, O. Carsi, pazar, ticaret ve Kapalıcarsi. Türkiye Is Bankasi Kultur Yayinlari, 2010

[13] Oktem, B. The Role of Global City Discourses in the Development and Transformation of the Buyukdere-Maslak Axis into the International Business District of Istanbul. International Planning Studies, 16(1), pp. 27-42, 2011

[14] Erbas, A.E., Ornek bir Prestij Konut Alani olarak Levent Mahallesi.tasarım+ kuram dergisi, 8(14), pp. 5-8, 2012

[15] Kocabas, A., The transition to low carbon urbanization in Turkey: Emerging policies and initial action. Habitat International, 37, pp. 80-87, 2013

[16] Erbas, A. E. \& Erbil, T. New Challenges in the transition of industrial areas within the Vision of Istanbul Metropolitan Plan for 2023, 2010

[17] DPT, Istanbul Uluslararasi Finans Merkezi Stratejisi ve Eylem Plani, 2009

[18] Staveren R., Commercial and Residential Deep Building Retrofits and the first "Cool District" of North America: The Wilshire Center Business Improvement District, Greenage II Symposium, MSFAU, Istanbul, 2012

[19] Wilshire Center Cool District Program, http://www.wilshirecenter.com /cooldistrict/ 